\title{
UMOWY GOSPODARCZE UE - WIETNAM - ANALIZA EKONOMICZNYCH I PRAWNYCH STOSUNKÓW POMIĘDZY STRONAMI
}

Parlament Europejski 12 lutego 2020 r. ratyfikował umowę o wolnym handlu (European Union Vietnam Free Trade Agreement, dalej: EVFTA), która współtworzy - wraz z umową o ochronie inwestycji (EU-Vietnam Investment Protection Agreement, dalej: EVIPA $^{1}$ ) - ramy prawne stosunków Unii Europejskiej i jej państw członkowskich z Wietnamem². Sa to pierwsze tego typu umowy UE podpisane z rozwijającym się krajem azjatyckim ${ }^{3}$. Ratyfikacja EVFTA przez legislatywę wietnamską planowana jest na maj $2020 \mathrm{r}$.

Wraz z ratyfikacją przedmiotowych umów zakończy się proces tworzenia ram prawnych stosunków gospodarczych pomiędzy stronami. Proces ten rozpoczął się w czerwcu 2012 r., następnie przez około 5 z 7 lat (od rozpoczęcia negocjacji do zakończenia procedury wiązania się umowami) umowy czekały na decyzje polityczne - negocjacje zamknięto w grudniu 2015 r. i od tego czasu strony szukały porozumienia taryfowego. Wreszcie 30 czerwca 2019 r. umowy zostały podpisane.

Umowy są ważnym prawno-instytucjonalnym efektem współpracy pomiędzy stronami, a zarazem moga znacząco wpłynąc na ich wzajemne stosunki (oraz na

ORCID: 0000-0002-7042-4592, DOI: 10.4467/23538724GS.20.018.12136

ORCID: 0000-0002-7744-8167, DOI: 10.4467/23538724GS.20.018.12136

1 Umowa wynika z regulacji traktatu z Lizbony, zgodnie z którą materia ta jest objęta kompetencjami dzielonymi pomiędzy UE i jej państwami członkowskimi (jest to efektem Opinii 2/15 Trybunału Sprawiedliwości UE na tle FTA z Singapurem).

2 Zwiazzaniu się EVIPA towarzyszyło wypowiedzenie 21 dwustronnych umów inwestycyjnych (BITs) państw członkowskich z Wietnamem. Umowy są ze sobą ściśle powiązane, co potwierdza m.in. art. 1.2 EVFTA, wskazujący, że celem umowy jest liberalizacja w odniesieniu nie tylko do handlu, lecz także inwestycji. Rozdzielenie umów ma na celu rozdzielenie ich ratyfikacji - oddzielenie materii znajdującej się w obszarze wyłącznych kompetencji UE od znajdujących się w obszarze kompetencji dzielonych. Teksty umów: https://trade.ec.europa.eu/doclib/press/index.cfm?id=1437 (dostęp: 1.03.2020).

3 Commission welcomes European Parliament's approval of EU-Vietnam trade and investment agreements, 12.02.2020, https://trade.ec.europa.eu/doclib/press/index.cfm?id=2114 (dostęp: 1.03.2020). 
relacje z innymi państwami). O ich wadze decyduje wiele czynników wewnętrznych i zewnętrznych. Wśród nich nie można pominąć kwestii wspomnianych niżej.

Po pierwsze, umowy są tworzone w warunkach turbulencji, które podważają funkcjonowanie multilateralnego systemu międzynarodowej współpracy gospodarczej. Wstrząsy obejmują zarówno normy, jak i instytucje. Do zamrożenia negocjacji na forum WTO (w formule Rundy Doha) dołączyły kolejne działania, głównie ze strony USA. Chodzi o wymuszenie zmian w NAFTA ${ }^{4}$, przerwanie negocjacji Transatlantyckiego Partnerstwa w dziedzinie Handlu i Inwestycji (Transatlantic Trade and Investment Partnership, TTIP), odstapienie od Partnerstwa Transpacyficznego (Trans-Pacific Partnership, TPP), wypowiedzenie paryskiego porozumienia klimatycznego, zablokowanie działania mechanizmu rozstrzygania sporów $\mathrm{WTO}^{5}$, a także Brexit. Wszystkie one składają się na wskazany proces. Państwa i instytucje międzynarodowe stoją wobec manichejskiej alternatywy: multi- albo unilateralizm, a wybór może zostać dokonany zarówno w procedurze porozumienia uniwersalnego (podtrzymania zmodyfikowanego systemu), jak i poprzez facta concludentia (upadek dotychczasowego ładu).

Po drugie, sa to pierwsze umowy UE po wystąpieniu z niej Wielkiej Brytanii ${ }^{6}$. Odzwierciedlają więc postrzeganie Unii w międzynarodowych stosunkach gospodarczych po Brexicie i będą punktem wyjścia dla ram prawnych stosunków pomiędzy Wielką Brytanią a Wietnamem ${ }^{7}$

Po trzecie, umowy te - jako kolejne już zawarte pomiędzy UE a państwami azjatyckimi - są ważnym elementem budowy mostu na linii Unia - Azja. Jest to

4 Renegocjacje NAFTA doprowadziły do jej zmian i podpisania nowej umowy 30 listopada 2018 r., tj. United States-Mexico-Canada Agreement. USMCA zmienia, zgodnie z oficjalnym stanowiskiem Ministerstwa Handlu USA, relacje pomiędzy stronami, formułę win-win zastępuje formuła win-lose „obustronnie korzystna wygrana dla północnoamerykańskich pracowników, rolników, hodowców i przedsiębiorstw" (United States-Mexico-Canada Agreement, https://ustr.gov/trade-agreements/free-trade-agreements/united-states-mexico-canada-agreement) (dostęp: 5.03.2020).

5 Od grudnia 2019 r. w konsekwencji zablokowania powołania nowych członków niemożliwe jest powołanie składu Organu Apelacyjnego do rozstrzygania odwołań od raportów panelu rozstrzygającego spór w pierwszej instancji.

6 Oczywiście trudno postrzegać je w kategorii potencjalnej substytucji Wietnamu w miejsce Wielkiej Brytanii, jednak nie można lekceważyć czynników współtworzących potencjał gospodarczo-społeczny Wietnamu, to znaczy według danych na rok 2020 ponad 97 mln ludności (wobec $65 \mathrm{mln}$ ) - w tym ok. $51 \mathrm{mln}$ to osoby aktywne zawodowo (Wielka Brytania - ok. $30 \mathrm{mln}$ ), powierzchnia $331212 \mathrm{~km}^{2}$ (Wielka Brytania $244820 \mathrm{~km}^{2}$ ) i PKB per capita wg parytetu sily nabywczej 7463 USD (wobec 46782 USD), siły zbrojne Wietnamu liczą 412 tys. żołnierzy (brytyjskie: około 400 tys.), zaś nakłady wojskowe oscyluja wokół 5,5 mld USD (Wielka Brytania 55,1 mld USD). Dane za: https://www.globalfirepower.com (data dostępu: 5.03.2020).

7 Pod względem wysokości bezpośrednich inwestycji zagranicznych (BIZ) brytyjskie inwestycje w Wietnamie ustępowały tylko holenderskim i francuskim, Wielka Brytania jest również ważnym adresatem eksportu z Wietnamu. Na temat poziomu BIZ zob. Guide to the EU-Vietnam Trade and Investment Agreements, s. 16, https://trade.ec.europa.eu/doclib/docs/2016/june/tradoc_154622.pdf (dostęp: 5.03.2020). 
szczególnie istotne wobec wyzwań, jakie stawiaja przed Unią i Zachodem w regionie Azji i Pacyfiku ich strategiczni rywale, tj. Rosja i Chiny oraz wobec niepewności wywołanej polityką USA (strategicznego partnera UE).

Po czwarte, UE, zawierając umowy z państwami azjatyckimi, może przyczynić się do budowy nowej architektury instytucjonalnej współpracy w sferze bezpieczeństwa w regionie Azji. W ten sposób bowiem Unia poszerza krag swoich azjatyckich partnerów (rdzeniem tego kręgu są uczestnicy Demokratycznego Diamentu Bezpieczeństwa, Democratic Security Diamond, czyli Australia, Indie i Japonia), a także wzmacnia współpracę państw ASEAN ${ }^{8}$. Powstanie takiej nowej architektury współpracy w regionie jest strategicznym celem UE ${ }^{9}$. Z kolei USA podobnie jak Chiny oparły bezpieczeństwo regionalne na asymetrycznych umowach bilateralnych $^{10}$ (a nie plurilateralnych, jak w przypadku traktatu waszyngtońskiego ${ }^{11}$ ) i w tym systemie rangę strategicznego partnera przypisano Japonii ${ }^{12}$. Zapewniło to Stanom Zjednoczonym maksymalny wpływ na państwa regionu, a jednocześnie zminimalizowało ryzyko wciagnięcia USA przez sojuszników z regionu w sprowokowany przez nich konflikt ${ }^{13}$. UE, budując współpracę w reżimie plurilateralnym, daje wyraz przekonaniu, że polityka państw regionu realizowana pod nowym przywództwem jest/będzie racjonalna i przewidywalna, respektująca uniwersalne wartości i normy.

${ }^{8}$ Negocjacje UE z ASEAN są w zawieszeniu, jednak umowy m.in. z Malezja, Tajlandia, Filipinami, Indonezja, Wietnamem oraz Singapurem są traktowane jako etap na drodze do kompleksowej umowy międzyregionalnej UE - ASEAN. ASEAN jest stroną 6 FTAs - z Chinami, Japonią, Koreą Południową, Indiami, Australią i Nową Zelandią oraz z Hongkongiem.

9 „Wietnam jest drugim po Singapurze krajem ASEAN, z którym UE zawarła umowy handlowe $\mathrm{i}$ inwestycyjne. Umowy te są zatem również ważnym krokiem w kierunku osiagnięcia ostatecznego celu UE, jakim jest zawarcie umów handlowych i inwestycyjnych z całym regionem ASEAN", Cecilia Malmström (komisarz ds. handlu), Foreword. Guide to the EU-Vietnam Trade and Investment Agreements, s. 7, https://trade.ec.europa.eu/doclib/docs/2016/june/tradoc_154622. pdf (dostęp: 5.03.2020).

10 Jest to system sojuszy typu ,piasta - szprychy”, to znaczy sieć dwustronnych sojuszy, w których jedno państwo odgrywa centralną rolę „piasty”, a inne - „szprych”, bez widocznych powiazań między soba. Por. V. Cha, Powerplay: The Origins of the U.S Alliance System in East Asia, „International Security” 2001, vol. 34, no. 3.

11 Odpowiednik struktury traktatu z 1949 r. został zainicjowany w Azji dopiero w 2006 r. w formule East Asia Summit. Jednak USA sygnalizowały gotowość do ewolucyjnej zmiany strategii w United States Security Strategy for the East Asia-Pacific Region (tzw. inicjatywa Nye) z 1995 r., http://worldjpn.grips.ac.jp/documents/texts/JPUS/19950227.O1E.html (dostęp: 5.03.2020).

12 Taką samą rolę przypisuje jej UE.

13 USA chciało ochronić region przed komunizmem, ale też świat przed III wojna. Politycy stojący na czele rządów sojuszniczych, tacy jak Syngman Ree (Korea Południowa), Chiang Kai-shek (Chiny) czy Ngô Đình Diệm (Wietnam Południowy) byli nieracjonalni (z perspektywy zachodniej) i nieprzewidywalni oraz skłonni do przemocy. To było wspólne dla nich i „komunistycznych" antagonistów. 
Po piąte, umowy są osadzone w kontekście społeczno-politycznym, jednocześnie jednak strony wskazują na obopólne korzyści gospodarcze, są to więc umowy win-win. Zawierajacc umowy o charakterze traité-loi (a nie traité-contrat), strony zademonstrowały wzajemne zaufanie wynikające z tego samego sytemu wartości. Umowy i ich implementacja są skorelowane $z$ wyznacznikami społeczno-polityczno-gospodarczych systemów w zakresie ich zbiorów wspólnych. Warunkami koniecznymi zawarcia umów były zaufanie oraz (ograniczona) wspólnota wartości. Implementacja umów zarówno podnosi poziom zaufania ${ }^{14}$, jak i poszerza katalog tych wspólnych wartości.

W pożądanym scenariuszu ewolucji stosunków międzynarodowych, w którym USA odejdzie od koncepcji America First, nowa architektura nie będzie oznaczała nowej budowli wzniesionej na gruzach poprzedniej. Możliwy i pożądany wydaje się patchwork uwzględniający różne elementy (normy i instytucje) i akceptujący konsekwencje różnic kulturowych. Strategiczny charakter modelu patchworkowego w przypadku UE przejawia się w łączeniu stosunków oraz umów bilateralnych z pluri- $\mathrm{i}$ multilateralnymi.

W artykule stawiamy tezę, że umowy z Wietnamem zawarte przez UE są elementem szerszej strategii, realizującej nie tylko cele gospodarcze, ale także społeczno-polityczne i wpływają one na stosunki zarówno pomiędzy stronami, jak i pluri-, a nawet multilateralne. Unia $\mathrm{w}$ ten sposób realizuje politykę zmiany przez hande ${ }^{15}$, implementującą bezpośrednio normy ustrojowe UE wyrażone w Traktacie o Unii Europejskiej podpisanym 7 lutego 1992 r. w Maastricht (TUE) ${ }^{16}$.

14 Są to już kolejne umowy pomiędzy stronami, co wskazuje na pozytywne doświadczenia wynikające z implementacji zobowiązań. Rozpoczęcie negocjacji EVFTA i EVIPA nastapiło bezpośrednio po zawarciu w czerwcu 2012 r. umowy o partnerstwie i współpracy (weszła w życie w październiku 2015 r.), która zastąpiła umowę o wspólpracy z 1995 r.

${ }_{15}$ W odniesieniu do Wietnamu działania te zostały zapoczątkowane w 2001 r. programem Multilateral Trade Policy Support Project (i kontynuowane w formułach MUTRAP’s: I, II, III) https:// vietnamnews.vn/economy/419332/eu-mutrap-project-promotes-viet-nams-deeper-tradeintegration.html (dostęp: 5.03.2020). Polityka „zmiany przez handel” w ramach umów handlowych jest realizowana poprzez obejmowanie ich zakresem także praw i wolności człowieka oraz monitoring implementacji postanowień. Przekłada się to na warunkowość udzielania i cofania korzyści. Na przykład w reżimie GSP+ UE cofnęła (przyznane) preferencje m.in. Białorusi, Sri Lance i Myanmarowi. Na temat warunkowości - klauzul praw człowieka w umowach UE zob. L. Bartels, A model human rights clauses for the EU's International Trade Agreements, German Institute for Human Rights, Berlin 2014.

${ }^{16} \mathrm{~W}$ myśl art. 3 ust. 5 TUE w stosunkach zewnętrznych Unia umacnia i propaguje swoje wartości i interesy oraz wnosi wkład w ochronę swoich obywateli. Przyczynia się do pokoju, bezpieczeństwa, trwałego rozwoju Ziemi, do solidarności i wzajemnego szacunku między narodami, do swobodnego i uczciwego handlu, do wyeliminowania ubóstwa oraz do ochrony praw człowieka, w szczególności praw dziecka, a także do ścisłego przestrzegania i rozwoju prawa międzynarodowego, w szczególności zasad Karty Narodów Zjednoczonych. Zgodnie z art. 21 ust. 1 działania Unii na arenie międzynarodowej oparte są na zasadach, które leżą u podstaw jej 
Dowodzimy, że umowy wzmacniaja trend instytucjonalizacji plurilateralizmu w relacjach zarówno pomiędzy państwami azjatyckimi, jak i tych państw z instytucjami i państwami spoza regionu (odchodzenie od modelu relacji „piasta - szprychy”), a ponadto podtrzymują uniwersalny system „,wolnego i uczciwego handlu”17 oraz budują współpracę transregionalną na rzecz powrotu do współpracy strategicznego partnera (USA) i powstrzymania strategicznych rywali (Chin i Rosji) zarówno UE, jak i Wietnamu.

Badanie ma charakter interdyscyplinarny, ekonomiczno-prawny. Analizujemy proces ustanawiania ram prawnych stosunków UE - Wietnam i ich kontekst w schemacie wnioskowań szkoły New Haven, łącząc go z ,racjonalnym wyborem"18, wykorzystującym metody i wnioskowania ekonomiczne.

\section{Antecedencje}

1. „Wrogowie na wieki”

Analizując stosunki UE - Wietnam, nie sposób uciec od nieodległej przeszłości ${ }^{19}$. Indochiny zostały skolonizowane przez Francję w drugiej połowie XIX wieku. Tę obecność przerwała japońska agresja w 1941 r. Francja dążłła następnie do odzyskania francuskich Indochin po zakończeniu II wojny światowej, czego nie popierały USA. Międzynarodowy konflikt zbrojny w Indochinach rozpoczął się w 1946 r. i jako I wojna indochińska trwał do 20 lipca 1954 r. ${ }^{20}$ Początek dało mu niezaakceptowanie ustaleń konferencji poczdamskiej (1945) o ustaleniu linii stref wpływów w Indochinach na północ i południe od 16. równoleżnika. Po okresie konfliktu wewnętrznego o małej intensywności, od 1949 r. eskalował on do wojny pomiędzy armiami Francji

\footnotetext{
utworzenia, rozwoju i rozszerzenia oraz które zamierza wspierać na świecie: demokracji, państwa prawnego, powszechności i niepodzielności praw człowieka i podstawowych wolności, poszanowania godności ludzkiej, zasad równości i solidarności oraz poszanowania zasad Karty Narodów Zjednoczonych oraz prawa międzynarodowego. Unia dąży do rozwijania stosunków i budowania partnerstwa z państwami trzecimi oraz z organizacjami międzynarodowymi, regionalnymi lub światowymi, które wyznają zasady, o których mowa w akapicie pierwszym. Sprzyja ona wielostronnym rozwiązaniom wspólnych problemów, w szczególności w ramach Organizacji Narodów Zjednoczonych.

17 Zob. program UE Trade for all. Towards a more responsible trade and investment policy, http://trade. ec.europa.eu/doclib/docs/2015/october/tradoc_153846.pdf (dostęp: 5.03.2020).

18 B.H. Druzin, Opening the Machinery of Private Order: Public International Law as a Form of Private Ordering, „Saint Louis University Law Journal” 2014, vol. 58, s. 450-465.

19 P. Ostaszewski, Wietnam: najdtusiszy konflikt XX wieku, Warszawa 2000.

20 J. Dalloz, La Guerre d'Indochine 1945-1954, Paris 1987.
} 
i Wietnamu ${ }^{21}$. Czynnikiem intensyfikującym tę wojnę i angażującym bezpośrednio USA stała się wojna w Korei (1950). Działania zbrojne objęły oprócz Wietnamu Laos i Kambodżę, skutkiem czego było uznanie przez Zachód wojny w Indochinach za krucjatę przeciwko komunizmowi. Niepowodzenia Francji w wojnie zamknęła porażka w bitwie pod Dien Bien Phu. W trakcie konferencji pokojowej w 1954 r. ustalono, że Indochiny zostaną podzielone wzdłuż 17. równoleżnika.

Kolejny etap wojny rozpoczął się 1 listopada 1955 r., a działania wojenne zakończyły się wraz z upadkiem Sajgonu 30 kwietnia 1975 r. Ta II wojna indochińska formalnie pomiędzy Wietnamem Północnym a Wietnamem Południowym - była de facto wojną pomiędzy blokiem wschodnim ${ }^{22}$ a Zachodem $^{23}$ i stała się ,gorąca wojną" (składowa „zimnej wojny”) toczoną nie bezpośrednio przez główne strony zimnowojennej konfrontacji, lecz przez ich przedstawicieli (tzw. proxy war ${ }^{24}$ ). W wojnie zginęły i zostały ranne miliony mieszkańców obu państw wietnamskich, Laosu i Kambodży oraz ponad 58 tys. obywateli USA.

Istotnym czynnikiem, który wpłynął na przebieg wojen w Indochinach, było ich postrzeganie przez opinię światową. Już I wojna indochińska została określona pod wpływem propagandy jako „brudna wojna”. Niechęć do polityki Zachodu wzrosła w czasie II wojny indochińskiej, a batalię o sympatię społeczeństwa zachodniego wygrał blok wschodni ${ }^{25}$. Konflikty w Indochinach przyczyniły się do zmian społecznych na Zachodzie i - jak się wydaje - były to jedyne trwałe zmiany.

Po zjednoczeniu Wietnamu ujawniało się coraz mocniej oblicze komunistów w regionie i na świecie. Masowe represje, które bezpośrednio pochłonęły ponad

21 Antagoniści korzystali z pomocy wojskowej USA, ZSRR i Chin.

22 ZSRR, Chiny i pozostałe państwa bloku w różnej formie bezpośrednio i pośrednio uczestniczyły w niej po stronie Wietnamu Północnego.

23 Wietnam Południowy był wspierany głównie przez USA, ale też przez Koreę Południowa, Filipiny, Tajlandię, Australię oraz inne państwa Zachodu. Nie sposób przecenić pomocy finansowej ze strony Europy Zachodniej (szczególnie Niemiec i Wielkiej Brytanii), która w wymianie handlowej akceptowała nadwartościową walutę amerykańską. E. Dickens, The Eurodollar Markeet and the New Era Global Financialization [w:] Financialization and the World Economy, ed. G.A. Epstein, Cheltenham - Northampton 2005, s. 213-216.

24 Są to wojny, w których „niepaństwowe grupy wojskowe korzystaja z bezpośredniej pomocy potęg zewnętrznych" (G. Hughes, My Enemy's Enemy. Proxy Warfare in international Politics, Chicago 2011, s. 11). W okresie zimnej wojny terminem tym określano wojny toczone regionalnie jako substytut bezpośredniej konfrontacji pomiędzy wielkimi mocarstwami (Y. Bar-Siman-Tov, The Strategy War by Proxy, „Cooperation and Conflict” 1984, vol. 29, issue 4, s. 263-273). Szerzej na temat wojny wietnamskiej: A. Axelrod, The Real History of the Cold War: a new look at the past, New York 2009, s. 336-380.

25 Symbolem wojny propagandowej jest sukces radzieckiego filmu Romana Karmena pt. Wietnam z 1954 r., przywołującego symbolikę, którą posługiwały się radzieckie filmy na temat II wojny światowej. Szerzej zob. S.L. Stanton, The Rise and Fall of an American Army: U.S. Ground Forces in Vietnam, 1963-1973, New York 1985. 
300 tys. ofiar, a także załamanie gospodarki spowodowały ucieczkę z Wietnamu ok. miliona osób (tzw. boat people) ${ }^{26}$. Szybko rozpadł się sojusz chińsko-wietnamski, czego symbolem jest wojna chińsko-wietnamska (określana jako III wojna indochińska), która rozpoczęła się 17 lutego 1979 r. atakiem na Wietnam i trwała niecały miesiąc, do 16 marca $^{27}$. ZSRR był w tym konflikcie względnie neutralny, udzielił Wietnamowi pomocy w postaci wyposażenia wojskowego. Atak stanowił reakcję na prześladowanie ludności narodowości chińskiej (Hao) w Wietnamie i wietnamską inwazję na Kambodżę w 1978 r. ${ }^{28}$ W sąsiedniej, również komunistycznej, Kambodży w latach 1975-1979 doszło do ludobójstwa, w wyniku którego zamordowano od 1,5 do 2 mln osób, czyli 1/4 ludności. Ofiarami zbrodni były różne grupy ludności, selekcja odbywała się na podstawie kryteriów społecznych, etnicznych, religijnych etc., generalnie jednak zbrodnia była masowa, systemowa i systematyczna ${ }^{29}$. Dopiero w odpowiedzi na bezpośredni atak Kambodży na Wietnam doszło do reakcji - wojska wietnamskie pokonały siły Kambodży i rozpoczęły jej okupację.

Komuniści długo zaprzeczali faktom i traktowali informacje o ludobójstwie jako wojnę propagandowa przeciwko państwom bloku wschodniego. Zmiana nastąpiła dopiero po zwycięstwie Wietnamu. Blok wschodni (ZSRR) poparł działania Wietnamu i przyznał, że ludobójstwo miało miejsce. Jednak spory pomiędzy antyzachodnimi państwami zaangażowanymi w wojny indochińskie, ujawnienie ich polityk wewnętrznych i ewolucja w kierunku pokomunistycznych dyktatur ${ }^{30}$ z prywatna - nierynkowa gospodarką ${ }^{31}$ pozbawiły te państwa zewnętrznego poparcia społecznego. Konflikty ideologiczne pomiędzy ekssojusznikami nadal trwają, wycofanie się Chin z terytoriów wietnamskich (1992) nie zakończyło sporów

26 Szerzej: Flight from Indochina [w:] The State of The World's Refugees 2000: Fifty Years of Humanitarian Action, UNHCR 2000, s. 98, https://www.unhcr.org/3ebf9bad0.html (dostęp: 10.03.2020).

27 D.C. Gampert, H. Binnedijk, B. Lin, Blinders, Blunders, and Wars. What America and China Can Learn. China's Punitive War against Vietnam, 1979, Rand Corporation 2014, s. 117-127. https:// www.rand.org/content/dam/rand/pubs/research_reports/RR700/RR768/RAND_RR768. pdf (dostęp: 10.03.2020).

28 Kambodża była okupowana do $1989 \mathrm{r}$.

29 A. Jones, Genocide. A Comprehensive Introduction, London - New York 2006, s. 185-206 oraz cytowana tam literatura; odesłanie do tej pracy nie jest równoznaczne z podzielaniem poglądów autora w odniesieniu do innych przypadków.

30 Reformy gospodarcze są realizowane w ramach polityki doi moi (odnowa), która nie obejmuje zmian w życiu społeczno-politycznym; Wietnam nie jest demokracją, jednak podnosi się poziom respektowania praw i wolności człowieka.

31 W ocenie CIA (https://www.cia.gov/library/publications/the-world-factbook/geos/ vm.html, dostęp: 10.03.2020) od 1986 r. trwa transformacja gospodarcza Wietnamu od sztywnej, centralnie planowanej gospodarki rolniczej w kierunku przemysłowej i rynkowej; jest to tzw. gospodarka mieszana. Podobne procesy przebiegają w Rosji, zob. F. Novokmet, Th. Piketty, G. Zucman, From Soviets to Oligarchs: Inequality and Property in Russia 1905-2016, http://www.piketty.pse.ens.fr/files/NPZ2017WIDworld.pdf (dostęp: 10.03.2020). 
granicznych ${ }^{32}$, Rosja w polityce, również wobec państw tego regionu, łączy ekspansjonizm z dążeniem do uzyskania jednostronnych korzyści (nie kieruje się żadnymi wartościami) ${ }^{33}$.

Do Wietnamu można odnieść powiedzenie, że „wszystko musiało się zmienić, żeby nic się nie zmieniło"34. Z jednej strony Wietnamczycy utracili wizerunek małego dzielnego narodu, który sam oparł się imperialistom. Z drugiej strony Wietnam funkcjonuje obecnie jako przewidywalny partner w stosunkach międzynarodowych, który w relacjach z innymi przestrzega zasad i norm prawa międzynarodowego, można więc z nim zawierać np. umowy handlowe i inwestycyjne.

\section{2. „Teoria domina” à rebours}

Amerykańskie zaangażowanie w Wietnamie i regionie Indochin było pochodne przyjęciu „teorii domina”. Zgodnie z nią efektem opanowania przez komunistów (reprezentujących ZSRR) jednego państwa miało stać się zdominowanie przez nich całego regionu, a potem reszty świata. W konsekwencji USA wraz z sojusznikami stawiało w poszczególnych regionach ,zapory ognia”, żeby powstrzymać marsz komunistów. W Azji Zachód postanowił ustawić zaporę na terytorium Wietnamu ${ }^{35}$. Odrębną (od „teorii domina”) kwestią jest wyznaczenie linii obrony, która ani nie musiała przebiegać w Wietnamie, ani Wietnam nie był do spełnienia tej roli predystynowany (ze względów geopolitycznych).

„Teoria domina” obecnie może przejawiać się w tym, że transformacja w Wietnamie współwystępuje ze zmianami w sferze stosunków międzynarodowych,

32 Spór dotyczy wysp Spartly i Paracel. Nie jest to jedyny spór graniczny Wietnamu; trwa m.in. spór z Kambodżą o wyspy przybrzeżne, z Brunei o przebieg granicy morskiej. Uogólniając, można stwierdzić, że w regionie każdy jest w sporze granicznym z każdym.

33 Zarzuciła popularną w państwach Trzeciego Świata retorykę „chorążego postępu”. Tak KC PZPR w liście z 6 marca 1953 r. do KC KPZR, Rady Ministrów i Prezydium Rady Najwyższej ZSRR określał Józefa Stalina: „Niezłomnego chorążego światowego obozu pokoju”, por. Do Komitetu Centralnego.... Dokumenty opublikowane w zwiqzku ze śmiercia Józefa Stalina, „Pamiętnik Literacki 1953, t. 44, nr 1, s. 3-8, http://bazhum.muzhp.pl/czasopismo/8/?idno=7144 (dostęp: 10.03.2020).

34 Il faut que tout change pour que rien ne change; G. Tomasi di Lampedusa, Gepard, Warszawa 2016.

35 Zob. wypowiedź prezydenta D.D. Eisenhowera podczas konferencji prasowej, która odbyła się 7 kwietnia 1954 r.: „Wreszcie masz szersze względy, które mogą być zgodne z tym, co można by nazwać zasadą »upadku domino«. Masz ustawiony rząd domino, przewracasz pierwsze, a to, co stanie się z ostatnim, to pewność, że przewróci się bardzo szybko. Tak więc można mieć początek rozpadu, który miałby najgłębsze konsekwencje" [tłum. własne], za: Introducing the domino theory, that if Vietnam fell to communism, the rest of Southeast Asia would soon follow, https://www.nps. gov/features/eise/jrranger/quotes2.htm (dostęp: 10.03.2020). Realizacja strategii zgodnej z ta teorią była wspólnym dziełem prezydentów Trumana i Eisenhovera (kontynuowanej przez następców), a wypracowanej przez George’a Kennana i Deana Acheso. Szerzej: V.D. Cha, Poverplay. The Origins of American Alliance System in Asia, New Jersey 2016. 
promieniując na zewnątrz. W styczniu $2007 \mathrm{r}$. Wietnam został przyjęty do WTO. W latach 2015-2016 zawarł kilka umów o wolnym handlu ${ }^{36}$, w tym - politycznie symboliczna - z Koreą Południową $\left(2015^{37}\right)$, a także z Euroazjatycką Unią Gospodarczą $\left(2016^{38}\right)$. Umowy z UE poprzedziło ratyfikowanie przez Wietnam 15 listopada 2018 r. Kompleksowego i Progresywnego Partnerstwa Transpacyficznego (Comprehensive and Progressive Agreement for Trans-Pacific Partnership, CPTPP) $)^{39}$.

Proces normalizacji stosunków Zachodu z Wietnamem przebiegał powoli. Dopiero po 20 latach od upadku Sajgonu ${ }^{40}, 11$ lipca 1995 r. prezydent USA Bill Clinton ogłosił formalną normalizację stosunków; biura łącznikowe podniesiono do rangi ambasad i otwarto dwa konsulaty. Podjęto regularny dialog polityczny na temat bezpieczeństwa, trwa dialog $\mathrm{w}$ odniesieniu do praw człowieka. Stosunki handlowe uregulowano umową z 2006 r. ${ }^{41}$ Współpraca obejmuje różne, istotne z punktu widzenia stron sfery ${ }^{42}$. Jednak obecnie stosunki te należą do najbliższych, jakie USA ma w tym regionie ${ }^{43}$. USA uznają Wietnam za ważnego partnera w regionie w odpieraniu strategicznego wyzwania ze strony Chin ${ }^{44}$. Podobnie strona wietnamska ocenia stosunki

36 Poprzedziła je umowa o partnerstwie gospodarczym (Economic Partnership Agreement) z Japonią (weszła w życie w 2009 r.) i FTA z Chile (2014).

37 Korea-Vietnam Free Trade Agreement, http://www.koreavietnamfta.org/en/selectFtaText.do (dostęp: 10.03.2020).

38 Free Trade Agreement between the Eurasian Economic Union and Vietnam to enter into force on October 5, http://www.eurasiancommission.org/en/nae/news/Pages/19-08-2016.aspx (dostęp: 10.03.2020). FTA z Wietnamem jest obok umowy z Chinami z 2019 r. jedyną znaczącą FTA zawartą przez EUG (pozostałe zawarto z Ukraina, Mołdową, Uzbekistanem, Egiptem, Tadżykistanem, Iranem i Serbia).

39 https://www.mfat.govt.nz/assets/CPTPP/Comprehensive-and-Progressive-Agreementfor-Trans-Pacific-Partnership-CPTPP-English.pdf (dostęp: 10.03.2020).

40 Powodów było wiele zarówno dwustronnych (chodzi o jeńców i groby żołnierzy - wg oficjalnych danych amerykańskich nieustalony jest los 1763 Amerykanów w Azji Południowo-Wschodniej, z tego 1353 w Wietnamie, brak również danych o 31 jeńcach spośród 883 ujętych w regionie, z tego $627 \mathrm{w}$ Wietnamie, zgodnie z Report of the Select Committee on POW/MLA Affaires United States Senate z 13 stycznia 1993 r. w Wietnamie nie są przetrzymywani jeńcy amerykańscy, https://fas.org/irp/congress/1993_rpt/pow-exec.html, dostęp: 10.03.2020), jak i będących efektem polityki prowadzonej przez Wietnam (wietnamski atak na Kambodżę). Rzecznikami otwarcia w polityce amerykańskiej wobec Wietnamu byli weterani, amerykańscy bohaterowie wojenni, senatorowie John McCain i John Kerry.

41 Od 2017 r. obowiązuje ustawa Permanent Normal Trade Relations w stosunku do Wietnamu, na mocy której Wietnam jest beneficjentem klauzuli najwyższego uprzywilejowania (KNU). Zarazem od 2020 r. Wietnam utracił w USA status „kraju rozwijającego się”, co poddaje go wymogom nieszkodzenia przemysłowi amerykańskiemu i pozbawia preferencji.

42 Wśród nich współpracę wymierzoną w produkcję narkotyków i handel nimi.

43 E. Albert, The Evolution of U.S.-Vietnam Ties, Council on Foreign Relations, https://www.cfr. org/backgrounder/evolution-us-vietnam-ties (dostęp: 11.03.2020).

44 „Wietnam wykazał najmniej złudzeń co do skutków wzrostu znaczenia Chin i największą gotowość do stosowania twardych, wyrafinowanych strategii w celu zapobieżenia dominacji Chin 
z USA, co wprost wyraził premier Wietnamu Nguyen Tan Dung 31 maja 2013 r. w wystapieniu otwierającym IISS Asia Summit Dialoque Shangri-La Dialoque ${ }^{45}$.

Można uznać - szczególnie w warunkach „wojny handlowej” USA - Chiny, że Wietnam jako kostka domina może wpłynać na globalną grę. O ile zwycięstwo komunistów w wyniku upadku niekomunistycznego rządu w Wietnamie nie doprowadziło do porażki Zachodu ani w Azji, ani na świecie, o tyle dołączenie Wietnamu do rodziny wolnych narodów może istotnie wpłynąć na kierunek rozwoju globalnych stosunków społecznych. W tym przypadku konsekwentna strategia polityczna UE, polegająca na „zmianie przez handel” (change through trade ${ }^{46}$ ), może się okazać skuteczniejsza od każdej innej strategii.

\section{Kontekst i treść umów}

\section{Waga determinantów gospodarczych}

Niezależnie od znaczenia, jakie strony przypisują wartościom i celom pozagospodarczym, wpływ na decyzję o zawarciu umów, ocenę ich skutków oraz na otoczenie międzynarodowe miały/maja/będą mieć efekty gospodarcze. Dlatego punktem wyjścia jest analiza ilościowo mierzonych potencjałów gospodarczych stron w ujęciu porównawczym.

na Morzu Południowochińskim i ogólnie w regionie"; J. Kurlantick, A China-Vietnam Military Clash. Contingency Planning Memorandum No. 26, Council on Foreign Relations, September 23, 2015, https://www.cfr.org/report/china-vietnam-military-clash (dostęp: 11.03.2020).

45 Stwierdził on: „Uważam, że żaden kraj regionu nie sprzeciwiłby się strategicznemu zaangażowaniu mocarstw spoza regionu, jeśli takie zaangażowanie ma na celu wzmocnienie współpracy na rzecz pokoju, stabilności i rozwoju. Moglibyśmy oczekiwać więcej w zakresie ról odgrywanych przez największe potęgi, zwłaszcza USA i Chiny, przy czym te dwie potęgi odgrywaja największą rolę (podkreślam, że największa) i są odpowiedzialne za przyszłość zarówno swoją, jak i regionu i świata. Ważne jest, aby takie oczekiwania zostały wzmocnione strategicznym zaufaniem i aby znalazło ono odzwierciedlenie w konkretnych i konstruktywnych działaniach tych narodów. Szczególną wage przywiązujemy do roli, jaką odgrywają dynamicznie rosnące Chiny i USA - mocarstwo Pacyfiku. Oczekiwalibyśmy, że strategie oraz działania USA i Chin będa zgodne z prawem międzynarodowym, będą respektować niepodległość i suwerenność narodów, nie tylko przynosząc korzyści im samym, ale także autentycznie przyczyniając się do naszego wspólnego pokoju, wspólpracy i dobrobytu; wówczas będziemy je wspierać”. Keynote Address, Building Strategic Trust for Peace, Cooperation and Prosperity in the Asia-Pacific Region, http://www. thanhniennews.com/politics/vietnam-pms-keynote-address-at-12th-shangrila-dialogue-2318. html (dostęp: 11.03.2020). Taka otwartość (czy wręcz brutalność) jest rzadko spotykana w kulturze azjatyckiej.

46 Szerzej zob. J. Wouters, A. Marx, D. Geraets, B. Natens, Global Governance through Trade EU Policies and Approaches, Cheltenham 2015. 
Jeśli poddać analizie pozycję gospodarczą Wietnamu, to zauważalne są ogromne zmiany, które nastapiły w ciagu ostatnich trzech dekad i skutkowały m.in. zmniejszeniem dystansu dzielącego go zarówno od innych krajów regionu, jak i Unii Europejskiej. Średnio od 1990 r. tempo wzrostu PKB Wietnamu wynosiło 6,8\% rocznie, podczas gdy w krajach o podobnym dochodzie (średnio-niskim według klasyfikacji Banku Światowego) wyniosło ono 4,8\%, a w krajach Azji Wschodniej i Pacyfiku ogółem - 4,2\%. Tempo wzrostu PKB w UE w tym okresie wynosiło średnio 1,8\% rocznie. Wprawdzie Chiny w tym czasie rozwijały się szybciej (średnio 9,4\% rocznie) niz Wietnam, ale w ostatnich latach nastapiło zrównanie tempa rozwoju tych dwóch gospodarek azjatyckich. Ponadto, Międzynarodowy Fundusz Walutowy (MFW) prognozuje na najbliższe lata wolniejszy wzrost PKB w Chinach niż w Wietnamie.

Co istotne, zarówno w latach kryzysu azjatyckiego (1997-1998), jak i niedawnego kryzysu finansowego (2008-2009) Wietnam okazał się bardziej odporny na wstrzasy, ani nie doświadczając tak gwałtownego zahamowania tempa wzrostu PKB (rys. 1), ani też nie notując bezwzględnego spadku dochodów per capita (co nastapiło w krajach Azji Wschodniej i Pacyfiku w latach 1997-1998 oraz w UE w latach 2008-2009).

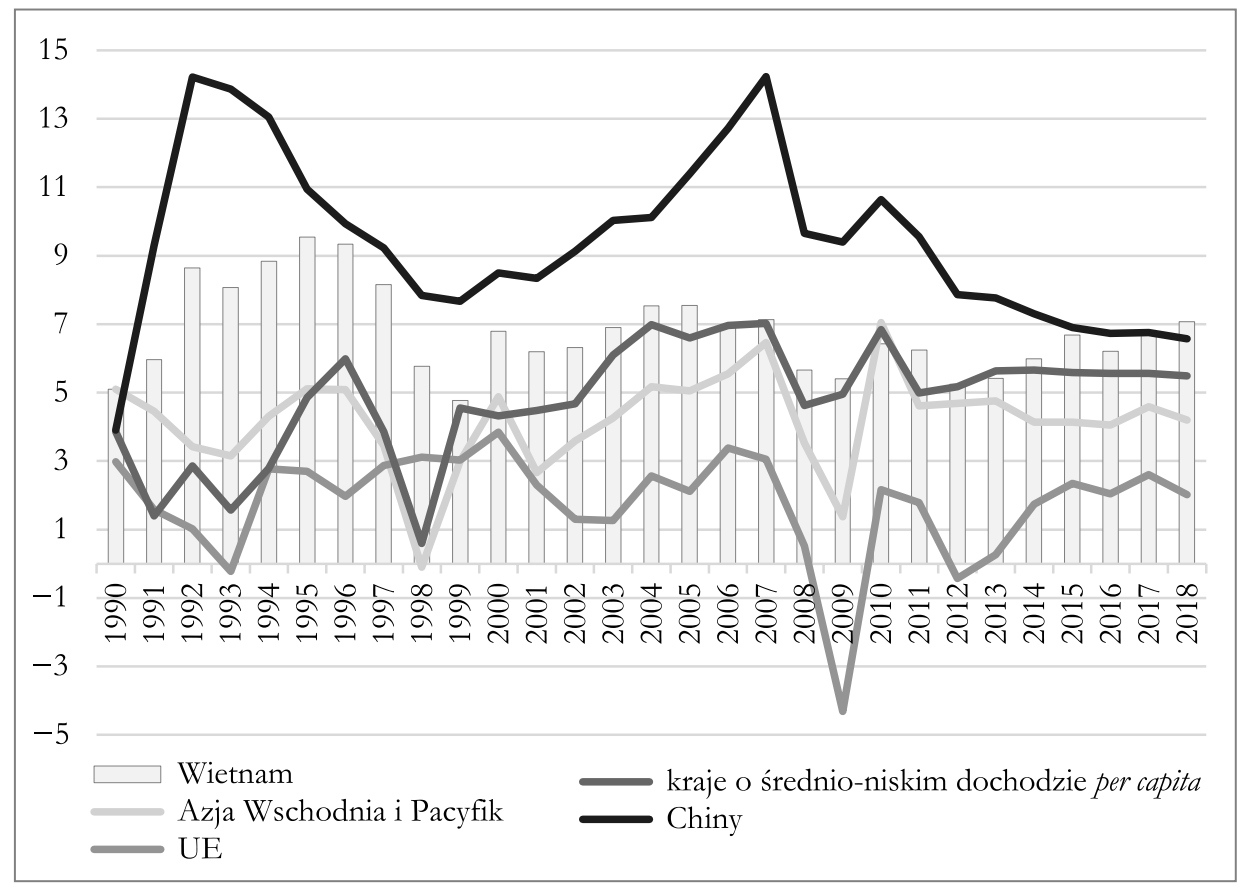

Rys. 1. Roczny wzrost PKB w Wietnamie na tle innych krajów i regionów

Źródło: Opracowanie własne na podstawie: World Bank, World Development Indicators, https:// databank.worldbank.org/ (dostęp: 1.03.2020). 
W efekcie relatywna zamożność Wietnamczyków bardzo wzrosła. O ile w 1990 r. dochód per capita w Wietnamie - liczony według parytetu siły nabywczej (purchasing power parity - PPP) w cenach stałych z 2011 r. - stanowił ok. 30\% PKB per capita krajów Azji Wschodniej i Pacyfiku, 52\% PKB krajów o średnio-niskim dochodzie oraz 6\% unijnego PKB per capita, o tyle w 2018 r. wartości te kształtowały się na poziomie odpowiednio: 38\%, 97\% i 17\% (rys. 2). Wyjątkiem jest relacja wietnamskiego PKB per capita do chińskiego. W 1990 r. wietnamskie PKB na osobę według PPP stanowiło prawie tyle samo co chińskie, natomiast w 2018 r. wartość ta w Wietnamie była o $60 \%$ niższa niż w Chinach. Biorąc pod uwagę prognozy MFW co do znacznie wyższego wzrostu PKB w Wietnamie w kolejnych latach niż w referencyjnych grupach krajów, dystans między Wietnamem a nimi będzie się zmniejszał.

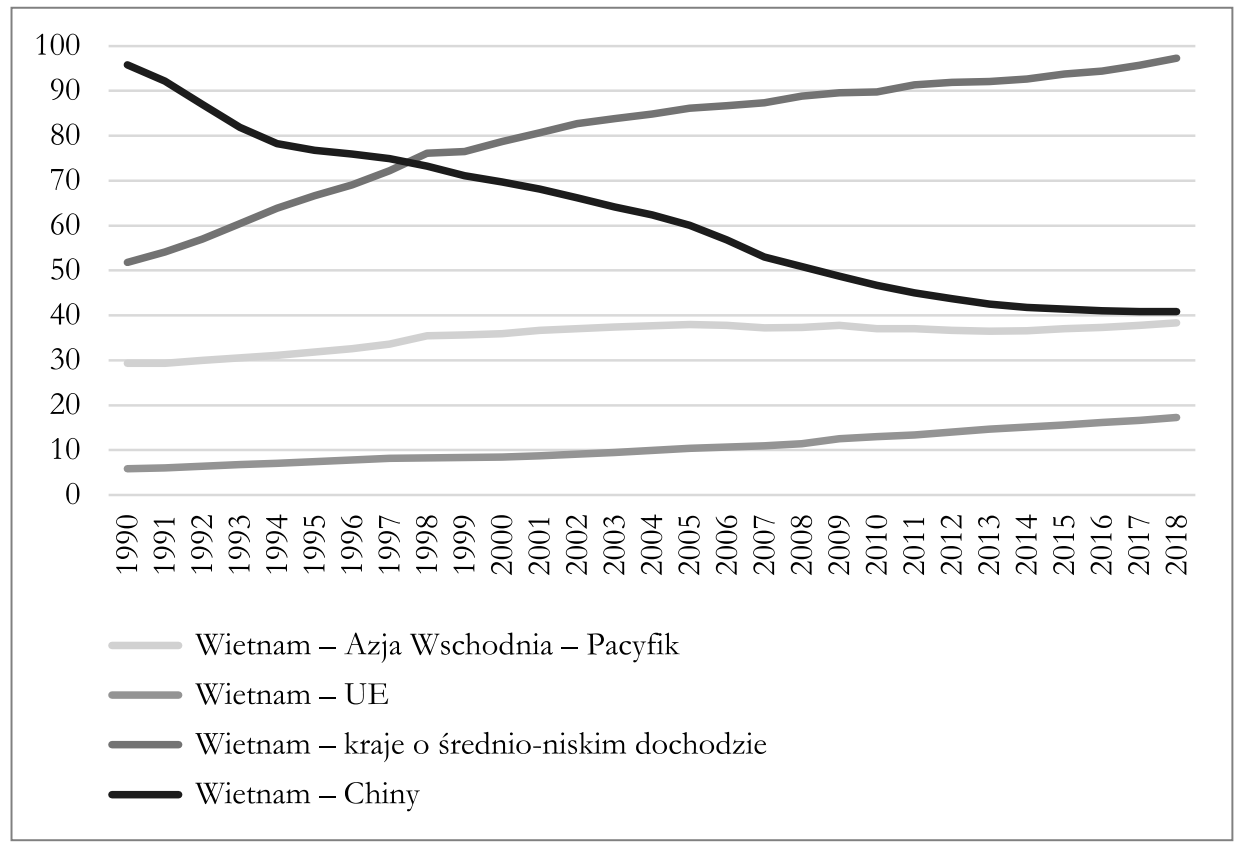

Rys. 2. Stosunek realnego PKB per capita (według PPP, ceny stałe z 2011 r.) Wietnamu do innych krajów i regionów (\%)

Źródło: Opracowanie własne na podstawie: World Bank, World Development Indicators, https:// databank.worldbank.org/ (dostęp: 1.03.2020).

W ostatnich latach wiele firm wielonarodowych przeniosło zakłady produkcyjne z Chin do Wietnamu w odpowiedzi na rosnące koszty pracy w Chinach i chęć zróżnicowania lokalizacji. Wprawdzie zawarty na początku 2020 r. rozejm między USA a Chinami w odniesieniu do polityki handlowej zmniejsza ryzyko napięć globalnych i w regionie, to nadal pozostaje ono wysokie, co sprawia, że atrakcyjność innych kra- 
jów regionu (w tym Wietnamu) rośnie. Ponadto, jak pokazują dane na rys. 3, występuje związek między wielkością napływu bezpośrednich inwestycji zagranicznych do Wietnamu a niepewnościa polityki gospodarczej w Chinach ${ }^{47}$. Z kolei pandemia COVID-19 z 2020 r. znacznie obniżyła działalność gospodarczą w Chinach i zakłóciła globalne sieci dostaw ${ }^{48}$, co przemawia przeciwko dotychczasowej strategii korporacji koncentrujących inwestycje w jednym miejscu i zwiększa szanse Wietnamu na przyciagnięcie jeszcze większych ilości kapitału zagranicznego ${ }^{49}$.

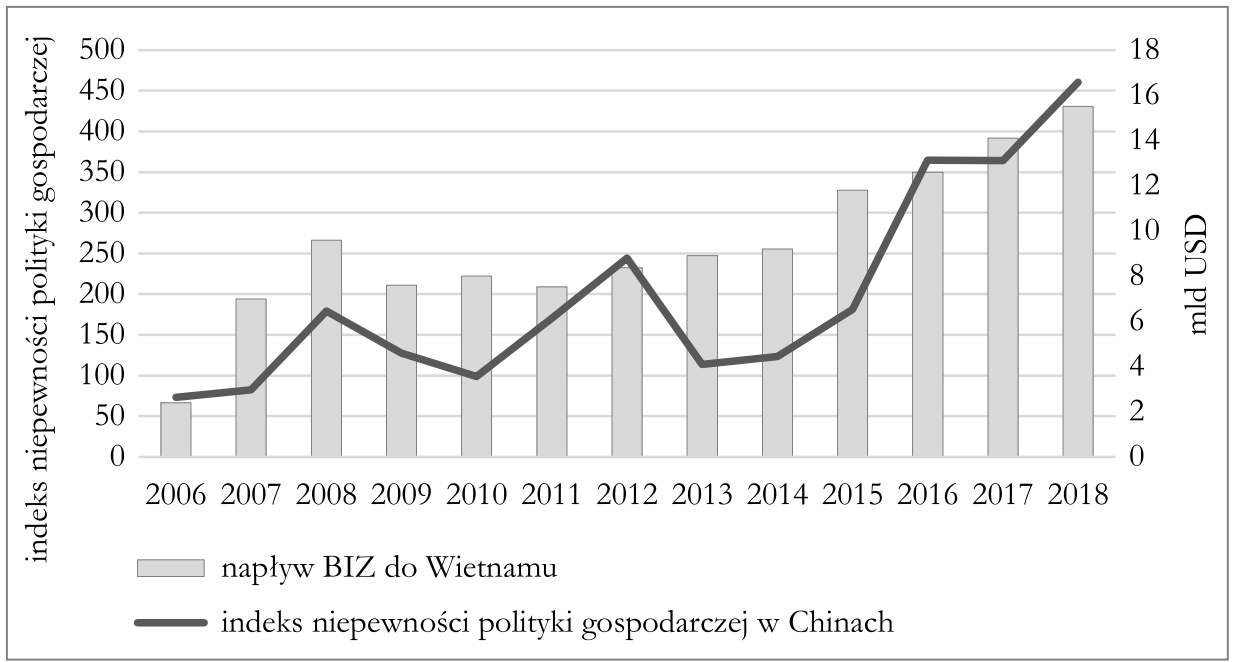

Rys. 3. Napływ BIZ do Wietnamu i indeks niepewności gospodarczej w Chinach

Źródło: Opracowanie własne na podstawie: China EPU Index Based on the South China Morning Post, https://www.policyuncertainty.com/scmp_monthly.html (dostęp: 10.03.2020) oraz UNCTAD statistics, https://unctadstat.unctad.org/ (dostęp: 10.03.2020).

47 Indeks jest konstruowany w oparciu o analizę artykułów w „South China Morning Post”, wiodącej anglojęzycznej gazecie w Hongkongu. Metodologia indeksu w: S. Baker, N. Bloom, S.J. Davis, Measuring Economic Policy Uncertainty, „Quarterly Journal of Economics”, November 2016, vol. 131, issue 4.

48 How Coronavirus Could Impact the Global Supply Chain by Mid-March, https://hbr.org/2020/02/ how-coronavirus-could-impact-the-global-supply-chain-by-mid-march?ab=hero-subleft-1\&fb clid=IwAR1pAf6QFYuwngwAeHTZBJbu-xo5NbLu74QhKiXDQZs0ScbBLjB-eDVFgOE (dostęp: 10.03.2020).

49 Mający spowolnić i ograniczyć pandemię lockdown spowodował ,wielką depresję" w gospodarce w skali świata („depresję” porównywaną z doświadczoną w latach 30. XX wieku). MFW przewiduje jednak już w 2021 r. powrót na ścieżkę wzrostu (por. World Economic Outlook, April 2020: The Great Lockdown, IMF, April 2020, https://www.imf.org/en/Publications/WEO/ Issues/2020/04/14/weo-april-2020, dostęp: 10.05.2020). Trudniej prognozować, jak doświadczenie przerwania łańcuchów dostaw wpłynie na przyszłe decyzje gospodarcze, to znaczy, w jakim stopniu regulatorzy instytucjonalni oraz przedsiębiorstwa będą skłonne dywersyfikować 
Jednym ze sposobów minimalizacji ryzyka związanego z potencjalnym wzrostem protekcjonizmu na świecie i zakłóceniem sieci dostaw w regionie jest aktywny udział Wietnamu w umowach liberalizujących handel i inwestycje. Temu celowi służą liczne porozumienia handlowe, których Wietnam jest strona.

Znaczenie umów o handlu i inwestycjach (EVFTA i EVIPA) zawartych przez UE i Wietnam dla każdej ze stron jest inne i w dużej mierze wynika z różnic w wielkości ich gospodarek. Gospodarka UE jest ok. 76 razy większa niż wietnamska ${ }^{50}$, przeciętny Europejczyk jest sześciokrotnie bardziej zamożny niż Wietnamczyk (według parytetu siły nabywczej) ${ }^{51}$, populacja Wietnamu jest ponad pięciokrotnie niższa niż UE. Struktura PKB Wietnamu jest przestarzała, charakterystyczna dla krajów o średnio-niskim dochodzie, z rolnictwem mającym prawie piętnastoprocentowy udział $\mathrm{w}$ tworzeniu wartości dodanej (jednak ulega on zmniejszeniu, z 39\% w 1990 r. i 24\% w 2000 r., głównie na rzecz przemysłu) przy prawie $40 \%$ zatrudnionych w tym sektorze (por. tab. 1). Od 1986 r. Wietnam dokonuje transformacji gospodarczej, a rząd wybrany w 2016 r. zadeklarował dalsza modernizację kraju i zmniejszenie roli państwa w gospodarce, walkę z korupcją i przyspieszenie reform administracyjnych w celu wspierania trwałego wzrostu gospodarczego opartego na sektorze prywatnym ${ }^{52}$. W związku z tym istnieje potencjał przesuwania czynników produkcji do przemysłu i usług oraz bardziej efektywnego ich tam wykorzystania. Daje to także szanse zyskownego wykorzystania tych możliwości przez podmioty z UE.

Wzajemne znaczenie UE i Wietnamu w handlu między nimi różni się, odzwierciedlając m.in. różnice wielkości ich gospodarek. Unia Europejska jest dla Wietnamu drugim po USA najważniejszym rynkiem zbytu towarów. W 2018 r. Wietnam wyeksportował do UE towary o wartości ok. 35,5 mld EUR, co stanowiło

źródła zaopatrzenia - ograniczać, w miarę możliwości, zależność od geograficznie odległych dostawców; w jakim stopniu i na jak długo zostaną zaakceptowane wyższe ceny w zamian za wyższe bezpieczeństwo łańcucha dostaw - przy podejmowaniu decyzji w odniesieniu do łańcuchów produkcji zostaną zmienione wagi przypisane ryzykom w relacji do wag przypisanych cenom.

${ }^{50}$ PKB UE w 2018 r. według bieżącego kursu wymiany wyniosło ok. 18,8 bln USD, a Wietnamu - 245 mld USD (dane Banku Światowego).

51 Realny PKB per capita według PPP w UE w 2018 r. (w cenach stałych z 2011 r.) wyniósł ok. 38,2 tys. USD, natomiast w Wietnamie ok. 6,6 tys. USD. Różnica zamożności jest jeszcze większa (czternastokrotnie), jeśli bierze się pod uwagę realny PKB per capita według bieżącego kursu wymiany (dane Banku Światowego).

${ }^{52} \mathrm{Na}$ przykład własność ziemi jest skoncentrowana w rękach państwa, ponieważ zgodnie z wietnamską konstytucją ziemia jest własnością publiczną i jest zarządzana w imieniu społeczeństwa przez państwo. Prawo do użytkowania gruntów nadane osobom prywatnym może zostać unieważnione w interesie krajowym po zapłaceniu odszkodowania. Article IV Consultation Press release; Staff Report; and Statement by the Executive Director for Vietnam, IMF Country Reports No. 19/235, July 2019. 
Tabela 1. Udział sektorów w tworzeniu wartości dodanej i zatrudnieniu w 2018 r. w Wietnamie, krajach o średnio-niskim dochodzie i UE (\%)

\begin{tabular}{|l|l|c|c|c|}
\hline \multicolumn{2}{|l|}{ Sektor } & UE & Wietnam & $\begin{array}{c}\text { Kraje o średnio-niskim } \\
\text { dochodzie per capita }\end{array}$ \\
\hline \multirow{2}{*}{ Rolnictwo } & wartość dodana & 1,5 & 14,7 & 14,9 \\
\cline { 2 - 5 } & zatrudnienie & 4,2 & 39,8 & 39,8 \\
\hline \multirow{2}{*}{ Przemysł } & wartość dodana & 21,7 & 34,2 & 28,8 \\
\cline { 2 - 5 } & zatrudnienie & 23,9 & 25,8 & 21,9 \\
\hline \multirow{2}{*}{ Usługi } & wartość dodana & 66,1 & 41,1 & 49,2 \\
\cline { 2 - 5 } & zatrudnienie & 72,0 & 34,4 & 38,2 \\
\hline
\end{tabular}

Źródło: Opracowanie własne na podstawie World Bank, World Development Indicators, https://databank.worldbank.org/ (dostęp: 1.03.2020).

prawie 18\% eksportu tego kraju ogółem. Według statystyk unijnych import UE z Wietnamu wyniósł wówczas 38 mld EUR ${ }^{53}$, stawiając ten kraj na 10. pozycji wśród dostawców towarów na rynek unijny, z udziałem prawie $2 \%$. W tym samym roku UE wyeksportowała do Wietnamu towary o wartości ok. $11 \mathrm{mld}$ EUR, co dało Wietnamowi 31. pozycję z udziałem $0,6 \% \mathrm{w}$ eksporcie zewnętrznym UE. Z kolei UE wartość ta dała 4. miejsce (po Chinach, Korei Południowej i Japonii) wśród najważniejszych importerów do Wietnamu ${ }^{54}$, z udziałem $6 \%$.

Dwustronna wymiana handlowa między UE i Wietnamem stale rośnie, począwszy od nawiązania między nimi stosunków dyplomatycznych w 1996 r., poprzez podpisanie w 2004 r. dwustronnego porozumienia o przystapieniu Wietnamu do WTO oraz porozumienia w sprawie dostępu do rynku ${ }^{56}$, aż wreszcie po przystapienie do WTO w 2007 r. W 2017 r. Wietnam znalazł się po raz pierwszy w dziesiątce największych eksporterów do UE. Łączna wartość obrotów w 2018 r. wyniosła ponad 49 mld EUR, z przewaga wietnamskiego eksportu do UE nad importem (rys. 4).

\footnotetext{
53 Asymetria w statystykach handlowych jest znanym problemem. Por. GUS, Handel ragranic₹ny. Statystyka lustrzana i statystyka asymetrii, Warszawa 2018; F. Fortanier, Towards merchandise trade statistics without asymmetries, „The OECD Statistics Newsletter” 2016, issue 64.

54 W pierwszej dziesiątce partnerów w imporcie znajduje się osiem państw z Azji, UE i USA.

55 European Union, Trade in goods with Vietnam. Detailed view, https://ec.europa.eu/trade/policy/ countries-and-regions/statistics/ (dostęp: 13.03.2020).

56 The Agreement on Market Access. Porozumienie to zawiesiło kontyngenty na wywóz odzieży z Wietnamu do UE od 1 stycznia 2005 r., na 3 lata przed jego formalnym przystapieniem do WTO. W zamian Wietnam zobowiązał się do zwiększenia dostępu do rynku dla dostawców z UE z różnych branż. Por. Guide to the EU-Vietnam..., s. 12.
} 


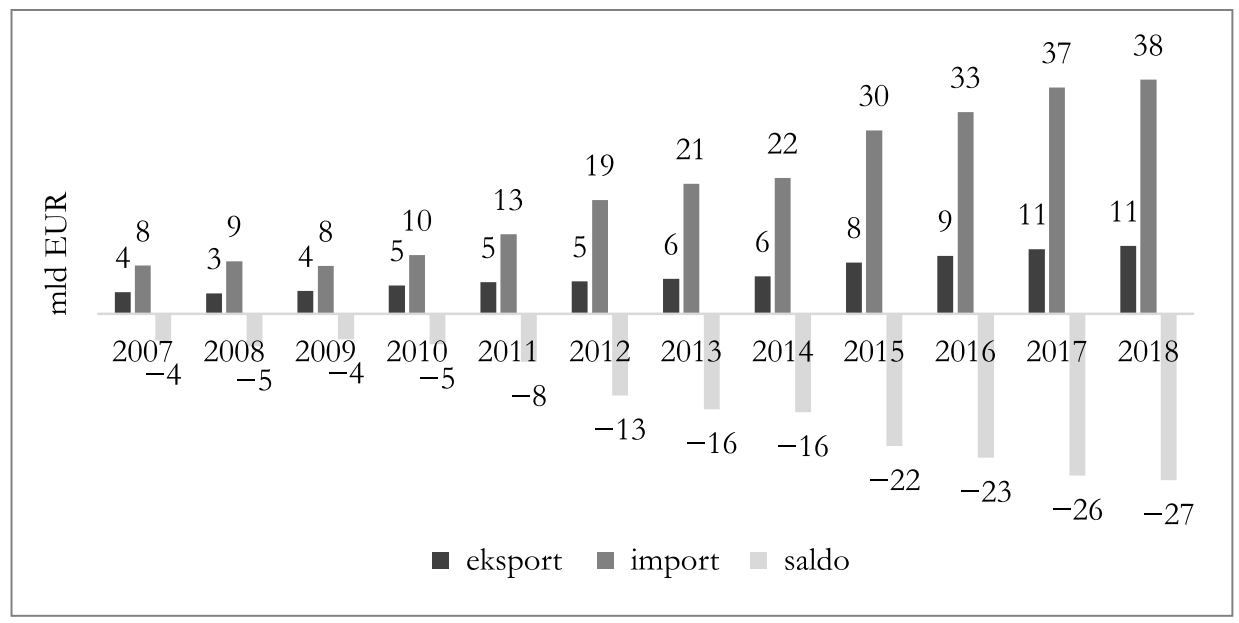

Rys. 4. Handel UE z Wietnamem - towary

Źródło: Opracowanie własne na podstawie danych Eurostatu.

Unia Europejska eksportuje do Wietnamu głównie maszyny i sprzęt transportowy, chemikalia i produkty rolne. W imporcie natomiast dominuje sprzęt telekomunikacyjny, odzież i produkty spożywcze ${ }^{57}$.

Wietnam w bardzo ograniczonym zakresie uczestniczy w światowym handlu usługami (osiaga ok. 0,3\% udziału w światowych obrotach), eksportując głównie usługi turystyczne, a importując - transportowe. Podobnie niskie są obroty usługowe z UE (w 2018 r. 4,4 mld EUR, a więc ponad 10 razy mniej niz w przypadku towarów). Unia w 2018 r. była eksporterem netto usług do Wietnamu, natomiast w poprzednich latach występowały znaczne wahania w bilansie handlu usługami (rys. 5).

Główną przeszkodą w rozwoju handlu usługami w Wietnamie jest niski poziom serwicyzacji gospodarki, związany z kolei z niedoborem wykwalifikowanych pracowników i dobrej infrastruktury, a także z nieefektywnym otoczeniem biznesowym, w którym wiele regulacji wewnętrznych utrudnia handel międzynarodowy ${ }^{58}$. Rosnący poziom wynagrodzeń, urbanizacji kraju i dynamiczny rozwój przedsiębiorczości prywatnej w połączeniu ze zmianami technologicznymi na świecie i umowami liberalizującymi wymianę usług dają szanse na przyspieszenie serwicyzacji gospodarki wietnamskiej.

57 European Union, Trade in goods...

58 An Overview and Examination of the Vietnamese Service Sector, U.S. International Trade Commission, 2012, https://www.usitc.gov/publications/332/Vietnam_working_Paper_final2a.pdf (dostęp: 13.03.2020). 


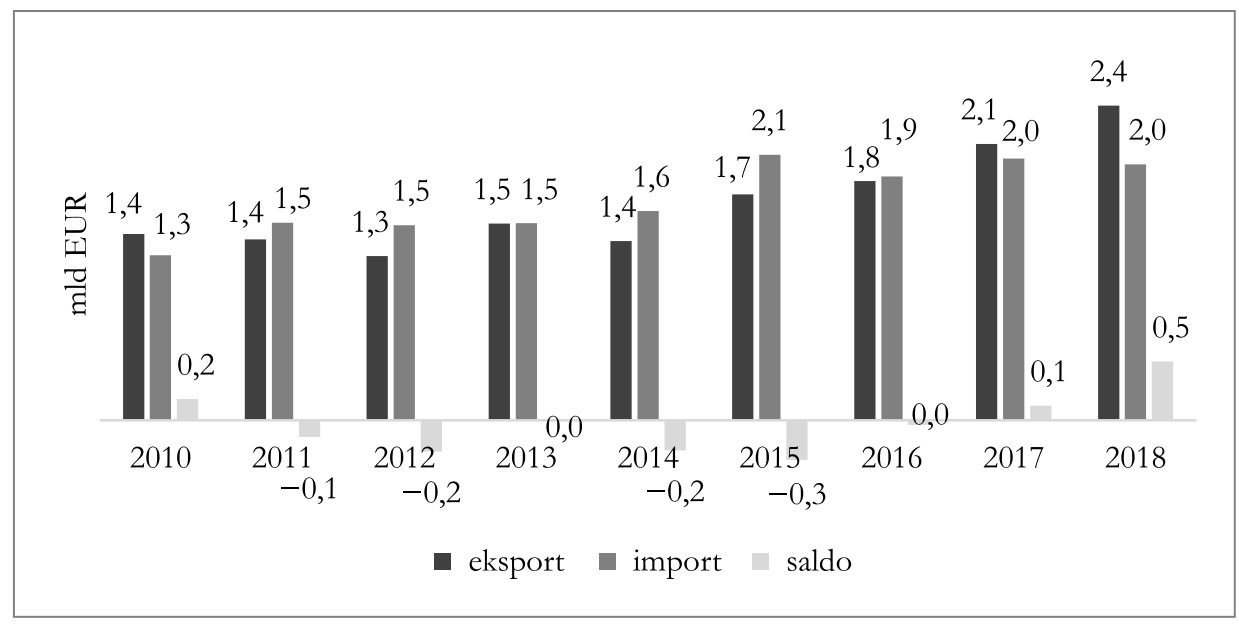

Rys. 5. Handel UE z Wietnamem - usługi

Źródło: Opracowanie własne na podstawie danych Eurostatu.

Do Wietnamu napływa coraz więcej bezpośrednich inwestycji zagranicznych (szczególnie od przystappienia do WTO), w tym z UE, która zajmuje 5. miejsce wśród 80 najważniejszych partnerów Wietnamu w zakresie zasobów BIZ ${ }^{59}$. W latach 2013-2017 nastąpiło niemal podwojenie zasobów unijnych BIZ w Wietnamie, jednak występują bardzo duże roczne wahania ich przepływu. Wietnamskie inwestycje w UE pozostają na niskim poziomie, jednak ich zasób także znacznie się zwiększył (tab. 2).

Tabela 2. Bezpośrednie inwestycje zagraniczne UE - Wietnam (mln EUR)

\begin{tabular}{|l|r|r|r|r|r|}
\hline \multicolumn{1}{|c|}{ Wyszczególnienie } & $\mathbf{2 0 1 3}$ & $\mathbf{2 0 1 4}$ & $\mathbf{2 0 1 5}$ & $\mathbf{2 0 1 6}$ & $\mathbf{2 0 1 7}$ \\
\hline Zasoby: napływ do UE & 33 & -28 & 135 & 1221 & 117 \\
\hline Zasoby: odpływ do Wietnamu & 4135 & 5255 & 7110 & 6286 & 6119 \\
\hline Przepływy: napływ do UE & -56 & -137 & 20 & -69 & -34 \\
\hline Przepływy: odpływ do Wietnamu & 3152 & 500 & 707 & 1232 & 129 \\
\hline
\end{tabular}

Źródło: Opracowanie własne na podstawie danych Eurostatu.

59 Guide to the EU-Vietnam..., s. 18. 
Negocjacje EVFTA i EVIPA przebiegały relatywnie szybko. Oficjalnie rozpoczęto je w czerwcu 2012 r., a zakończono w grudniu 2015 r. Przez kolejne 5 lat trwały spory o szczegółowe regulacje taryfowe, co może dowodzić albo staranności w negocjacjach, albo krótkowzroczności: brakuje analizy, jak mają się straty pochodne 5 latom opóźnienia w wejściu w życie umowy do bronionych korzyści ${ }^{60}$. Paradoksalnie jednak zwłoka zagrała na korzyść umów. Z jednej strony kolejno wchodziły w życie umowy UE z państwami regionu (m.in. Japonią i Singapurem). Z drugiej strony w międzyczasie wzrastała ranga partnerów w obrotach wzajemnych: Wietnam awansowa ${ }^{61}$ na 2 . miejsce wśród państw ASEAN jako partner handlowy $\mathrm{UE}^{62}$.

\section{Treść EVFTA}

Analiza obejmuje treść umów istotną z punktu widzenia weryfikacji hipotez badawczych, to znaczy postanowienia wskazujące na cel unormowań oraz przywołujące wartości, regulujące szeroko ujmowany zakres praw i wolności człowieka (w tym praw pracowniczych i socjalnych), a także dotyczące zrównoważonego rozwoju oraz ustanowienia nowego reżimu rozstrzygania inwestycyjnych sporów międzynarodowych.

EVFTA jest umową nowej generacji ${ }^{63}$, co oznacza, że obejmuje zakresem przedmiotowym: 1) materię ustanawiającą strefę wolnego handlu (liberalizacja barier taryfowych i pozataryfowych), przewidując - tak jak klasyczna FTA - stopniowe

${ }^{60} \mathrm{~W}$ sytuacji, gdy okres przejściowy liberalizacji wyznaczono umową na 10 lat (w istotnych sferach, m.in. tekstylia i farmaceutyki, nawet na czas krótszy, bo 7 lat), odłożono efekt o połowę okresu.

${ }^{61}$ Jest to zwiąane z tempem rozwoju Wietnamu; w ocenie (na podstawie ekstrapolacji trendów) PwC Wietnam może być najszybciej rozwijająca się dużą gospodarką na świecie w okresie do 2050 r., która do tego czasu wzrośnie do 20. miejsca w światowym rankingu PKB. W tej samej prognozie dopuszcza się spadek poniżej 10\% udziału PKB UE27 w światowym PKB. Shift of global economic power to emerging economies set to continue in long run, with India, Indonesia and Vietnam among star performers, 7 February 2017, https://www.pwc.com/jp/en/press-room/worldin-2050-170213.html (dostęp: 12.03.2020).

${ }^{62} \mathrm{~W}$ tym czasie ASEAN stał się trzecim partnerem handlowym UE (po USA i Chinach). Dalej jednak głównym partnerem handlowym Wietnamu są USA, z obrotami wzajemnymi 255,5 mld USD w 2019 r. (wykazującymi stały wzrost - w 2018 r. wynosiły 242,6 mld USD). Wolumen obrotów UE - Wietnam stanowi ok. 16\% wolumenu obrotów USA - Wietnam.

${ }^{63}$ Jednak jest to nowość relatywna, gdyż materia ta - acz w ograniczonym wymiarze - była już obecna w umowie ramowej o wszechstronnym partnerstwie i współpracy (umowa zawarta w 2012 r., weszła w życie w 2016 r.), Framework. Agreement on Comprehensive Partnership and Cooperation Between The European Union and Its Member States, Of The One Part, and The Socialist Republic of Viet Nam, Of The Other Part, https://eeas.europa.eu/sites/eeas/files/pca.pdf (dostęp: 12.03.2020). 
znoszenie ceł, eliminację albo ograniczenie barier technicznych (uznawalność standardów), sanitarnych i fitosanitarnych (nie obniżają one jednak ochrony zdrowia i konsumenta); 2) likwidację ograniczeń usługodawców w dostępie do rynków (liberalizacje w sferze usług finansowych, telekomunikacyjnych, transportowych, pocztowych, kurierskich etc.); 3) normy bezpośrednio związane z gospodarką (jednak nieobecne we wcześniejszych FTA), jak normy regulujące ochronę własności intelektualnej, oznaczenia geograficzne, dostęp do rynku zamówień publicznych oraz ułatwienia w zakresie partnerstwa publiczno-prywatnego, etc.

Nowe w stosunku do dotychczasowych FTA - sprzężone jednak z gospodarką, choć postrzegane przez UE przede wszystkim przez pryzmat reprezentowanego i promowanego w stosunkach zewnętrznych systemu wartości - są normy regulujące materię zrównoważonego rozwoju (w odniesieniu do środowiska) ${ }^{64}$, ochrony praw człowieka $^{65}$, praw pracowniczych ${ }^{66}$ oraz „sprawiedliwego handlu” (fair and ethical

${ }^{64}$ Należy tu uwzględnić paryskie porozumienie w sprawie klimatu; strony umów rozwijaja i wzmacniają regulacje obecne w EU-Vietnam Framework. Cooperation Agreement. Umowy potwierdzaja zobowiązania stron do respektowania, oprócz paryskiego porozumienia, umów i regulacji odnoszących się do: zrównoważonego rozwoju, ochrony i zrównoważonego zarządzania dziką fauną i florą, bioróżnorodnością, a także leśnictwem i rybołówstwem; zob. art. 13.1 umowy. Jest to zgodne z unijnym standardem: „Wielostronne Porozumienia w sprawie Ochrony Środowiska (MEA) są instrumentami, za pomocą których społeczność międzynarodowa reaguje na globalne i transgraniczne wyzwania środowiskowe, w tym walkę ze zmianami klimatu. Porozumienia takie obejmują m.in. Ramową Konwencję Narodów Zjednoczonych w sprawie zmian klimatu, w tym porozumienie paryskie i Konwencję o różnorodności biologicznej lub Konwencję o międzynarodowym handlu gatunkami zagrożonymi wyginięciem". Feedback and way forward on improving the implementation and enforcement of Trade and Sustainable Development chapters in EU Free Trade Agreements, https://www.politico.eu/wp-content/uploads/2018/02/TSD-Non-Paper.pdf (dostęp: 12.03.2020).

65 Wietnam zobowiązał się do respektowania (europejskich) standardów w zakresie rokowań zbiorowych, zakazu pracy przymusowej, ale i przyznania pracownikom wolności związkowych prawa do tworzenia wolnych związków zawodowych. Ma to nastapić poprzez przystapienie Wietnamu do odnośnych konwencji Międzynarodowej Organizacji Pracy (MOP). Wietnam w 2019 r. zrewidował kodeks pracy. W sferze praw człowieka umowy zawierają klauzulę warunkowości. UE nie traktuje zobowiązań w odnośnym zakresie jako formalnych. Wskazuje na to wszczęcie sporu z Koreą Południową w związku z uznaniem, że nie wykonuje ona zobowiązań przyjętych w ramach FTA.

${ }^{66}$ Oczywiście respektowanie tych norm i standardów przez strony umów gospodarczych chroni je przed nierównoprawnością pochodną dumpingowi (socjalnemu, ekologicznemu, etc.). Również w dążeniu do przyciagnięcia inwestycji strony zobowiązały się do niedziałania w schemacie race to the bottom (w odniesieniu do praw pracowniczych szerzej zob. C.W., Racing to the bottom: Countries skimp enforcement of decent working conditions to get FDI, ,The Economist”, 27 November 2013), jednak oczywiście w wyścigu państwa rezygnuja z ochrony nie tylko praw pracowniczych, lecz także praw i wolności człowieka czy wymogów środowiska. Jako argument na rzecz poszerzenia kręgu podmiotów akceptujących te normy UE odwołuje się do wartości innych niż gospodarcze. Elementem implementacji jest zobowiązanie do ratyfikacji ośmiu podstawowych konwencji 
trade). Strony uznały, że współodpowiedzialne za monitoring implementacji tych zobowiązań będą instytucje i organizacje społeczeństwa obywatelskiego ${ }^{67}$. Przyjęte w EVFTA rozwiązania w zakresie zrównoważonego rozwoju współtworzą schemat wykonawczy regulacji w umowach handlowych europejskiego modelu zrównoważonego rozwoju ${ }^{68}$. Zgodnie z tym schematem w EVFTA materia zrównoważonego rozwoju została wyodrębniona w formule części nazwanej Trade and Sustainable Development Chapter (TSD) ${ }^{69}$. Zakres TSD w EVFTA jest szeroki i obejmuje materię społeczna, praw pracowniczych i środowiskowa ${ }^{70}$. Odnośne regulacje współtworza trzy filary w ramach FTA: 1) zobowiązania FTA zostały ściśle powiązane $\mathrm{z}$ wielostronnymi umowami międzynarodowymi, w tym, co jest istotnym novum, konwencjami Międzynarodowej Organizacji Pracy (MOP); 2) umowa przewiduje działanie (a w Wietnamie, de facto, przyzwolenie władz na powołanie ${ }^{71}$ ) instytucji społeczeństwa obywatelskiego wdrażających i monitorujących wdrażanie zrównoważonego rozwoju; 3) ustanowienie w ramach EVFTA mechanizmu rozstrzygania sporów w odniesieniu do sporów z zakresu implementacji zobowiązań.

\section{EVIPA - rozwiązanie modelowe}

Umowa tworzy nowy model instytucyjnego systemu rozstrzygania sporów na linii inwestor - państwo. Wraz z odnośnymi normami EVFTA można ją zaliczyć do umów inwestycyjnych trzeciej generacji (International Investment Agreements) ${ }^{72} . \mathrm{Na}$

MOP-u i podstawowych MOP-owskich uzgodnień wielostronnych. UE mianem podstawowych konwencji MOP-u określa te konwencje, które obejmują zagadnienia uznawane za podstawowe zasady i prawa w pracy, powszechnie popierane przez społeczność międzynarodową: wolność zrzeszania się i rzeczywiste uznanie prawa do rokowań zbiorowych, eliminację wszelkich form pracy przymusowej lub obowiązkowej, skuteczną likwidację pracy dzieci oraz eliminację dyskryminacji w zakresie zatrudnienia i wykonywania zawodu. Feedback and way forward... Na ramy regulujące inwestycje wskazuje preambuła do umowy.

${ }_{67}$ Ta formalna dwustronność zobowiązań ma kamuflować fakt, że UE i jej państwa członkowskie zrealizowały te zobowiązania w odległej przeszłości - było to dla „nowych” członków warunkiem admisji.

${ }^{68}$ Zgodnie z polityką UE uzgodnione rozwiązania będą powielane; zob. Feedback and way forward...

${ }^{69}$ Wyodrębnienie części poświęconej TSD w każdej unijnej FTA jest celem UE.

${ }^{70}$ Obejmuje to również wspieranie działań na rzecz „odpowiedzialnego prowadzenia działalności gospodarczej”. UE finansuje i współrealizuje (wraz z OECD i MOP-em) w stosunkach z państwami Azji (analogicznie do współpracy z Meksykiem i MERCOSUR) tworzenie odpowiedzialnych łańcuchów dostaw.

71 Instytucje te objęte są unijnym programem wsparcia, m.in. finansowego.

72 Szerzej zob. C. Titi, The evolution of substantive investment protections in recent trade and investment treaties, „Opinion”, 12.11.2018, http://www.ictsd.org/opinion/the-evolution-of-substantive-investment-protections-in-recent-trade-and-investment (dostęp: 12.03.2020); Recent Developments in 
mocy umowy zostanie powołany Stały Trybunał Inwestycyjny (STI), złożony z dziewięciu stałych i niezależnych sędziów; a spór będzie rozstrzygał skład trzyosobowy. Postępowanie będzie dwuinstancyjne, od orzeczeń STI będzie przysługiwać apelacja do sześcioosobowego Stałego Trybunału Arbitrażowego (orzekającego w składach trzyosobowych). Podstawą apelacji może być nie tylko naruszenie prawa oraz interpretacja prawa ${ }^{73}$, lecz także „,nieustalenie stanu faktycznego”. Umowa przewiduje przejrzystość procedowania ${ }^{74}$. Strony zobowiązały się do wykonywania (uznania) ostatecznego charakteru rozstrzygnięć $^{75}$. Umowa zakazuje inwestorom praktyki forum shopping. Koszty postępowania uregulowano ogólnie w formule loser-pay principle. Przyjęte rozwiązanie jest traktowane przez UE jako wzorzec, zgodnie z którym ma zostać ukształtowany system uniwersalny ${ }^{76}$.

\section{Podsumowanie}

Przeprowadzone badanie pozwoliło pozytywnie zweryfikować sformułowaną tezę. Podpisując umowy o handlu i ochronie inwestycji, UE realizuje politykę „zmiany [Wietnamu] przez handel". Wietnam jest w procesie szukania równowagi między socjalizmem a kapitalizmem, między „poleganiem na własnych siłach”77 a współpracą, między regionalizmem a uniwersalizmem. Umowy z UE włączają go w system powiązań międzynarodowych. Współpraca pomiędzy stronami umów wnosi wartość dodaną każdej ze stron (win-win) poprzez relacje bezpośrednie, lecz także dywersyfikując zasób ich partnerów w stosunkach gospodarczych. Wzrasta dynamika procesu instytucjonalizacji więzi pomiędzy państwami Azji i nimi a UE. Zdarzenia mające miejsce od początku 2020 r. w instytucjach WTO w postaci zahamowania upadku systemu rozstrzygania sporów pozwalają na optymizm w ocenie zdolności multilateralnego porządku międzynarodowego do (samo)obrony.

the International Investment Regime, UNCTAD, May 2018, issue 1, https://unctad.org/en/PublicationsLibrary/diaepcbinf2018d1_en.pdf (dostęp: 12.03.2020).

73 Jest to podstawa klasyczna.

74 Pewnym paradoksem z tej perspektywy jest fakt niezwiązania się przez żadne państwo członkowskie UE (wg stanu aktualnego: https://treaties.un.org/pages/ViewDetails.aspx?src= TREATY\&mtdsg_no=XXII-3\&chapter=22\&lang=en, dostęp: 12.03.2020) Konwencją Narodów Zjednoczonych o przejrzystości w umowach regulujących arbitraż inwestor - państwo z 2014 r.

75 W tym zakresie przewidziano pięcioletni okres przejściowy na korzyść Wietnamu.

76 Negotiating Directives for a Convention Establishing a Multilateral Court for the Settlement of Investment Disputes, http://data.consilium.europa.eu/doc/document/ST-12981-2017-ADD-1-DCL-1/en/ pdf (dostęp: 12.03.2020).

77 Tzw. self-reliance policy; J. Galtung, Trade or Development. Some Reflections on Self-Reliance, „Economic\&Politic Weekly" 1976, vol. 11, no. 5, s. 223 i nn. 
SUMMARY

\section{ECONOMIC EU-VIETNAM AGREEMENTS: THE ANALYSIS OF ECONOMIC AND LEGAL RELATIONS BETWEEN THE PARTIES}

The aim of the study is to identify the effects of free trade and investment protection agreements between the EU and Vietnam. We argue that these agreements are part of a broader strategy, pursuing not only economic but also socio-political objectives. They affect relations between the parties, but also have a pluri- or even multilateral dimension. 